(11) Nordiska

ministerrådet

NORDISKT

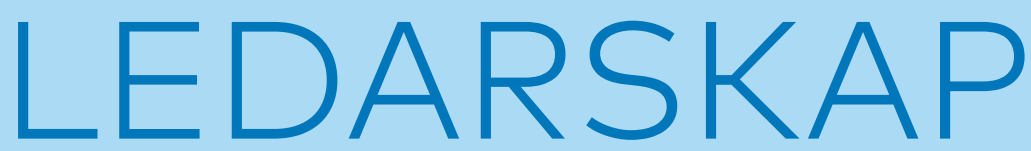

Under årtiondena efter andra världskriget växte en särskild nordisk ledarskapsstil fram. Denna rapport sammanfattar studier som karaktäriserat den nordiska ledarskapsstilen i gränslandet mellan ledarskap, kultur och värderingar. Vad särskiljer den från ledarskapsstilar i övriga världen? Dessutom för rapporten fram ett perspektiv på hur den uppkommit utifrån några specifika faktorer i de nordiska samhällena. 


\section{Nordiskt ledarskap}

Ulf Andreasson

ANP 2018:831

ISBN 978-92-893-5877-4 (PRINT)

ISBN 978-92-893-5878-1 (PDF)

ISBN 978-92-893-5879-8 (EPUB)

http://dx.doi.org/10.6027/ANP2018-831

(C) Nordiska ministerrådet 2018

Layout: Jette Koefoed

Tryck: Rosendahls

Printed in Denmark

\section{Det nordiska samarbetet}

Det nordiska samarbetet är ett av världens mest omfattande regionala samarbeten. Det omfattar Danmark, Finland, Island, Norge och Sverige samt Färöarna, Grönland och Åland.

Det nordiska samarbetet är politiskt, ekonomiskt och kulturellt förankrat och en viktig del av europeiskt och internationellt samarbete. Den nordiska gemenskapen arbetar för ett starkt Norden i ett starkt Europa.

Det nordiska samarbetet vill stärka nordiska och regionala intressen och värderingar i en global omvärld. Gemensamma värderingar länderna emellan bidrar till att stärka Nordens ställning som en av världens mest innovativa och konkurrenskraftiga regioner.

\section{Nordiska ministerrådet}

Nordens Hus

Ved Stranden 18

DK-1061 Köpenhamn K

www.norden.org

Ladda ner och beställ nordiska publikationer: www.norden.org/nordpub 
NORDISKT LEDARSKAP 


\title{
Innehåll
}

\author{
7 Förord \\ 8 Sammanfattning \\ 10 Inledning \\ 11 Historik \\ 13 Ledarskap, värderingar och kultur \\ 15 Den nordiska ledarskapsstilens karaktär \\ 20 Ledarskapets rötter och framväxt \\ 25 Sammanfattning, utfall och kritik \\ 27 Nordiskt ledarskap inför framtiden \\ 29 Bilaga: Några studier om \\ ledarskap, värderingar och kultur \\ 33 Litteratur
}



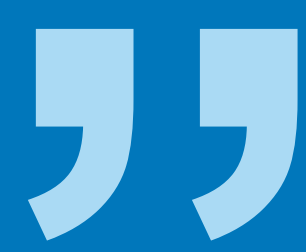

Ledarskapet utövas alltid i ett samspel med det omgivande samhället. Det innebär att ledarskap tenderar att se olika ut över världen, helt enkelt för att samhällen och de värderingar de är uppbyggda kring skiljer sig åt. 


\section{Förord}

Ledarskap är svårt att fånga och definiera, men på en grundläggande nivå är det något som sker i relation till andra individer och fungerar som ett verktyg för att nå mål och lösa uppgifter; ett sätt att skapa resultat.

Ledarskapet utövas alltid i ett samspel med det omgivande samhället. Det innebär att ledarskap tenderar att se olika ut över världen, helt enkelt för att samhällen och de värderingar de är uppbyggda kring skiljer sig åt. Detta är något som många som provat på att arbeta i andra länder eller internationella miljöer kan känna igen.

Denna rapport behandlar ledarskap på det sätt det utövas i Norden. Författarna har försökt hitta de kvalitéer som separerar det nordiska ledarskapet från andra ledarskapsstilar i världen. Rapporten berör också frågor som: Hur har den nordiska ledarskapsstilen uppkommit? Går det att identifiera skiljaktigheter mellan de nordiska länderna?

Rapporten bygger på tidigare forskning om nordisk ledarskapsstil. Mest uppmärksamhet förefaller temat ha fått åren 1990-2010. Det förefaller dock som ämnet väckt nytt intresse under senare tid med flera publicerade studier och ytterligare några inplanerade. Denna rapport kan ses som en fristående tolkning av resultaten i de tidigare studierna; texten är på många sätt således en kunskapsöversikt. Förhoppningen är att den kan fungera som en startpunkt för diskussioner om ledarskapsfrågor i Norden. Frågan är aktuell utifrån de förändringar vi kan förvänta oss framöver, och inte minst i relation till förändringar i samband med det som ofta benämns den fjärde industriella revolutionen.

Det ska påpekas att det är en inte enkel balansakt att å ena sidan peka ut och diskutera en distinkt nordisk ledarskapsstil, liksom också andra kulturella företeelser för den delen, och å andra sidan inte falla ner i stereotypa beskrivningar av nationella identiteter.

Rapporten är författad av UIf Andreasson med hjälp av Mikael Lundqvist vid analys- och statistikenheten vid Nordiska ministerrådets sekretariat. Rapporten ingår i enhetens rapportserie som ska belysa aktuella ämnen som är centrala i ett nordiskt perspektiv.

Köpenhamn, november 2018

\section{Dagfinn Høybråten}

Generalsekreterare

Nordiska ministerrådet 


\section{Sammanfattning}

Ett antal studier har fokuserat på samspelet mellan ledarskap, kultur och värderingar. Utifrån dessa studier hävdas att det finns en särskild nordisk ledarskapsstil. Dess kännetecken är bl.a. delegering av makt och ansvar till medarbetare samt hög grad av konsensussökande där alla medarbetares röster är viktiga. Den nordiske ledaren betonar också nödvändigheten av samarbete. Han eller hon nedtonar vidare sin auktoritet och fungerar ofta snarast som ett slags coach för medarbetarna. Det är också viktigt att ledaren ska kunna inspirera medarbetarna och vara visionär men samtidigt realistisk.

Nordiska företag har en ledarskapskultur som överlag skapar mer engagerade och arbetssamma anställda. Den representerar en samarbetsmodell som ger en god grogrund för kreativitet. Den har även skapat en symbios mellan anställda och företag där båda sidor har en insikt om betydelsen av varandra och tar ansvar för helheten.

Ledarskapet i Mellanöstern och Afrika söder om Sahara har i studier utpekats som mest annorlunda jämfört med den nordiska. Längst ifrån är ändå, enligt samma studier, den östeuropeiska, medan den latinamerikanska och den anglosaxiska världen istället har pekats ut att ha ledarskapsstilar som ligger ganska nära den nordiska.

Hur har den nordiska ledarskapsstilen uppstått? Om man ser närmare på utvecklingen i Norden under 1900-talet framstår kompromisser och önskan om att balansera olika intressen i samhället som ett genomgående drag i de nordiska samhällena. De nordiska samhällena kan sägas ha eftersträvat balanspunkter för aktörer med närmast motstående intressen, särskilt inom arbetsmarknadsområdet. Konsekvenserna av detta har sannolikt blivit att ledarrollen inte har samma status som i många andra länder, och att ledaren fungerar som en coach för medarbetarna, snarare än auktoritär despot. Även aspekter som konsensus och samarbete, vilka pekats ut som viktiga kännetecken för det nordiska ledarskapet, kan kopplas till detta. Vi kan, sannolikt utifrån samma aspekter, också se höga nivåer av ansvarstagande och tillit inom organisationerna.

En annan bakgrund till den nordiska ledarskapsstilen gäller välfärdsstatens uppbyggnad. Det tidigindustriella paternalistiska förhållandet mellan arbetsgivare och arbetstagare i Norden kom en bit in på 1900-talet att luckras upp och ersättas med en relation mellan, i första hand, arbetstagaren och välfärdsstaten. Det har påpekats att den nordiska välfärdsmodellen har en stark individualistisk dimension. På ett djupare plan handlar individualismen i detta sammanhang om att den enskilde (arbetstagaren) inte har ett starkt beroende till arbetsgivaren. En nordisk ledare måste således förhålla sig till att inte kunna förvänta sig att medarbetaren uppfattar sig som starkt avhängig av arbetsgivaren eller -platsen. Sannolikt är det en drivkraft bakom den platta organisationsstrukturen.

Norden består vidare av små och öppna ekonomier. De är också kunskapsintensiva och exportorienterade ekonomier som befinner sig i framkanten av den tekniska utvecklingen. Detta har skapat behov för anpassningsförmåga. Det innebär vidare att medarbetare har en hög utbildningsnivå och stark identitet 
i det arbete man utför. En konsekvens av detta är flexibilitet inför förändringar, där ledaren ansvarar för att peka ut en långsiktig riktning för de närmast självgående medarbetarna.

Det är inte svårt att tillerkänna den nordiska ledarskapsstilen ett betydande värde för dess förmåga att skapa förutsättningar för hög produktivitet, innovationsförmåga och tillväxt, och samtidigt ha hög trivsel och god arbetsmiljö. En forskare menar att det som gör det meningsfullt att tala om en specifik nordisk ledarskapsmodell är dess strävan att kombinera ekonomisk tillväxt med demokratisk stabilitet. Det är en beskrivning som förefaller ge god mening.

Det finns även kritik mot den nordiska ledarskapsmodellen, bland annat att den uppfattas som närliggande begreppet "ledarskapsstilen", där beslut fattas på andra platser inom organisationen eller uppfattas som "givna". Ledarskap handlar istället om administration och personalfrågor. Erfarenhet, professionellt omdöme eller en kollegas synpunkter gör på så sätt stora sjok av traditionell arbetsledning mer eller mindre överflödig. Det finns även en tendens att ett sådant ledarskap undviker ansvar. En annan kritik gäller nordiska företags avsaknad av tydliga hierarkier, vilket kan bli problematiskt när de har verksamhet $\mathrm{i}$ andra länder.

Vi upplever idag ett tekniskt skifte som i grunden kan komma att förändra samhället, ekonomin, förutsättningarna för företagande, arbetsorganisation och inte minst ledarskapet Avslutningsvis diskuterar rapporten några teman som är betydelsefulla för framtiden för den nordiska ledarskapsstilen: stakeholder-perspektivet, etik och utbildning.

I Norden har exempelvis företagen en närmare och mer symbiotisk relation till det omkringliggande samhället, särskilt jämfört med amerikanska företag. Det inkluderar en annan syn på ansvarstagande: inte minst att vårda relationerna till sina intressenter (stakeholders). Intressenterna kan vara av olika typer. Hit hör exempelvis anställda, kunder och leverantörer, men även fackföreningar, frivilligorganisationer och personer som kanske bor nära företaget. Man kan säga att nordiska företag inte bara har ekonomisk vinst som samhällsansvar, utan ett betydligt bredare perspektiv.

Kärnan i den nordiska ledarskapsstilen utgörs av flera etiska överväganden, som hur man exempelvis ser på demokrati, människovärde, ansvar, plikt, rättigheter samt individens roll i förhållande till kollektivet. Att långsiktigt främja en etisk dimension i den nordiska ledarskapsstilen kan likställas med att understödja centrala grundvärderingar i våra samhällen. De värderingar som hittills väglett ledarskapsfrågor i Norden har särskilt gällt öppenhet, integritet och tillit.

Utbildning är på många sätt nyckeln till den nordiska ledarskapsstilen, dels i förståelsen att medarbetare tack vare vidareutbildning kan vara flexibla, vilket ger dem möjlighet att bland annat ta ett stort ansvar inom organisationerna, dels är utbildning centralt utifrån att framtidens ledare vid universitet och högskolor studerar ledarskapsfrågor ur ett brett perspektiv och inte enbart ur ett amerikanskt ledarskaps- och arbetsorganisationsperspektiv, vilka tenderar att prioritera kortsiktighet. 


\section{Inledning}

Ledarskap behövs i alla typer av organisationer och grupper. Det kräver en definition och avgränsning av ansvarsområden, huvudsaker och bisaker samt uppdragsgivarens, medarbetarnas och kundernas och andra gruppers intressen. En ledare behöver vidare utveckla konsten att balansera mellan ofta motsatta krafter och dessutom styra och ange riktning. Ledarskap är heller inte en konstant enhet, utan förändrar sig över tid och mellan olika kulturer. Denna rapport handlar specifikt om utformningen av det moderna ledarskapet i Norden. För att förstå detta är det nödvändigt med en inledande historisk tillbakablick samt en jämförelse med utformningen av ledarskapet i övriga världen. ${ }^{1}$

Det finns en tendens att betrakta ledarskap i offentlig verksamhet som en eftersläpning utifrån den privata sektorn. En studie utifrån en nordisk horisont har dock inte kunnat finna några större skillnader mellan sektorerna. Andersen, "Public versus Private Managers: How Public and Private Managers Differ in Leadership Behaviour", i Public Administration Review (okänt årtal). Det är också utgångspunkten för denna rapport. 


\section{Historik}

Sannolikt fanns under den tidiga industrialiseringen i Norden inte någon särskild nordisk variant av ledarskap. ${ }^{2}$ I praktiken byggde ledarskapet under den tidiga industrialiseringen i de nordiska länderna - liksom i många andra europeiska länder - på paternalism. Det innebar att relationen mellan den anställde och ägaren var personlig och omfattade mer än bara arbetet. I utbyte mot lojalitet till fabriksägarna fick den anställde (inklusive familjen i övrigt) livslång säkerhet vilket kunde inkludera boende, sjukvård, barnomsorg med mera. Den paternalistiska omsorgen skapade ett slags faderligt förhållande mellan den anställda och ledarskapet. Baksidan var ett starkt beroende från den anställde till ägarna, vilket ofta ackompanjerades av låga löner. Drivkraften för systemet var primärt fabriksägarnas beroende av de anställda. ${ }^{3}$

Perioden kring sekelskiftet fram till första världskriget kopplas ofta samman till vad som kallas den andra industriella revolutionen. Den brukar karaktäriseras av genombrottet för elektricitet och förbränningsmotorer. Men andra förändringar var också betydelsefulla, såsom masskonsumtionens genomslag och nya principer för produktion med Henry Fords löpande band som förebild. Även om utvecklingen skiljer sig mellan länderna kom industrin i Norden att koncentreras till större enheter, vilket ledde till att företag byråkratiserades. En effekt av detta var att chefer inte längre nödvändigtvis utgjordes av ägarna till företaget, utan av anställda. Det ledde i sin tur till att ledarskapet blev mer systematiskt. Inspiration hämtades från de tidiga teoretikerna på området i USA och Tyskland, och inte minst kom taylorismen att ha betydelse. ${ }^{4}$ En mer specifik nordisk ledarskapsstil växte fram först efter andra världskriget. ${ }^{5}$

En god startpunkt att förstå ledarskapsstilar i en global kontext är utifrån den forskningstradition som ser närmare på relationerna mellan ledarskap, värderingar och kultur. ${ }^{6}$
Under perioden fram till första världskriget byråkratiserades många nordiska företag. Det innebar att chefer inte längre nödvändigtvis utgjordes av ägarna, utan av anställda. Ledarskapet blev därigenom mer systematiskt. Inspiration kom särskilt från taylorismen. Det var först efter andra världskriget som det uppstod en särskild nordisk ledarskapsstil.

\footnotetext{
2 Byrkjeflot et al., The Democratic Challenge to Capitalism. Management and Democracy in the Nordic Countries (red., 2001).

3 Jul Nielsen, "Lifelong Care and Control. Paternalism in Nineteenth-Century Factory Communities", i Ethnologia Scandinavica, 24 (1990); Jul Nielsen, "Industrial Paternalism in the 19th Century. Old or New?", i Ethnologia Europaea (2000); Magnusson, Arbetet vid en svensk verkstad: Munktells 1900-1920 (1987).

$4 \quad$ Se flera av kapitlen i Byrkjeflot et al. (red., 2001).

5 Myklebust (2001); Grenness,"Scandinavian Managers on Scandinavian Management", i International Journal of Valve-Based Management 16 (2003). Selnes,"Market orientation in United States and Scandinavian companies: A cross cultural study", i Journal of Scandinavian Management 12 (1996).

$6 \quad$ Kulturbegreppet och teorier om kultur är notoriskt svårt. Det finns en uppdelning i forskningen där kultur för några forskare baseras på gemensamma föreställningar, till skillnad från andra forskare som snarare betonar normer och värderingar. Alvesson, Organisationskultur och ledning (2009, 2. uppl.). I detta sammanhang syftar kulturbegreppet till att identifiera likheter och skillnader mellan kulturer och att kategorisera dem. Guirdham, Communicating Across Cultures at Work (2005).
} 



\section{Ledarskap, värderingar och kultur}

Den kanske mest kända forskningen inom fältet är den som utförts av nederländaren Geert Hofstede. Det började med att Hofstede fick tillgång till en databas om värderingar från ett stort antal individer i över 50 länder runt om i världen. Det gemensamma var att de arbetade i de lokala dotterbolagen till ett stort multinationellt företag: IBM. De flesta delar av organisationen hade till och med undersökts två gånger över ett fyraårsintervall, vilket medförde att databasen innehöll mer än 100000 enkäter.

Hofstedes bok Culture's consequences7 , som första gången utgavs 1980, har blivit en klassiker och en av de mest citerade böckerna inom samhällsvetenskap. ${ }^{8}$ Uppmärksamheten beror till stor del på att Hofstede var den första som skapade ett kulturellt ramverk på nationell nivå som innehöll flera olika kulturella dimensioner. Forskningen har återkommande uppdaterats under årtiondena efter att han publicerade den första boken.

Andra har tagit vid efter Hofstede. I den så kallade Globe-studien, samlade forskare in data från inte mindre än 17300 ledare på mellannivå från över 60 länder runt om i världen, vilka representerade närmare 1000 organisationer. ${ }^{9}$ Studien är uppbyggd kring sex globala ledarskapsdimensioner, eller som man uttrycker "kulturellt stöttade implicita teorier om ledarskap". En kärnfråga är att komma fram till vad som uppfattas som ett gott, effektivt ledarskap. ${ }^{10}$

Metodmässigt bryter studierna ner ledarskapet i olika dimensioner för att komma på djupet på ledarskapets utformning. ${ }^{11}$ De ger ett slags språk att tolka kulturfenomen. Det är viktigt att påpeka att de inte ska ses som givna, determinerade utfall, utan snarare handlar om sannolikheter. Ofta startar studierna på nationell nivå för att sedan skapa kulturella kluster - där Norden är ett ofta förekommande kluster. I rapportens bilaga redovisas studierna ytterligare.
Studiet av relationerna mellan ledarskap, värderingar och kultur är en god startpunkt för att förstå ledarskapsstilar.
Hofstede, Culture's Consequences: International differences in work related values (1980). http://blogs.lse.ac.uk/impactofsocialsciences/2016/05/12/what-are-the-most-cited-publicationsin-the-social-sciences-according-to-google-scholar/

Finland, Danmark och Sverige ingår i studien.

10 House et al. (red.), Culture, Leadership, and Organizations. The GLOBE Study of 62 Societies (2004); Lindell \& Arvonen, "The Nordic Management Style in a European Context", i International Studies of Management \& Organization 26 (1996).

11 Forskningen har även mött en del kritik, bland annat för ett subjektivt inslag i modellerna. För att i någon mån balansera den kritiken är det viktigt att inte bara se på en studie. 

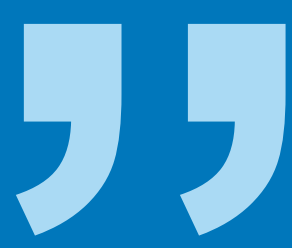

I en nordisk kontext är det centralt att en ledare lyssnar till alla medarbetare i samband med beslutsfattande och implementering av beslut, snarare än att han eller hon betonar sin auktoritet. Ledaren ska huvudsakligen fungera som en slags coach som ska inspirera och motivera medarbetare. 


\section{Den nordiska ledarskapsstilens karaktär}

Hur ser då utfallet ut för Norden? Det första man kan konstatera är att resultatet är relativt väl samlat i de olika studierna. ${ }^{12}$ Det styrker att det finns anledning att hävda att det finns en särskild nordisk ledarskapskultur. Det nordiska ledarskapet pekas i studierna ut, i jämförelse med andra länder, som präglat i högre grad av följande faktorer:

- Det nordiska ledarskapets organisationsstruktur kan beskrivas som platta organisationer, med hög grad av delegering av makt och ansvar. Samtidigt ställs höga krav på medarbetarens prestationer. Medarbetarens insatser bedöms också huvudsakligen utifrån individ, snarare än grupp. Över huvud taget är det individualistiska perspektivet starkt i det nordiska ledarskapets utformning.

- Norden har i mindre utsträckning formalitet inom sina organisationer, men samtidigt en hög grad av informella regler och procedurer, och inställningen "så gör vi här" är ofta förekommande. Nordiska idéer ses vidare som universella och kan tillämpas var som helst i världen. Det är t.o.m. svårt att avvika från dessa idéer, även om organisationen befinner sig utanför Norden.

- I en nordisk kontext är det centralt att en ledare lyssnar till alla medarbetare i samband med beslutsfattande och implementering av beslut, snarare än att han eller hon betonar sin auktoritet. Ledaren ska huvudsakligen fungera som en slags coach som ska inspirera och motivera medarbetare. Ledarskapet ska drivas utifrån visioner, som dock måste vara realistiska. Medarbetarna följer ledaren av egen fri vilja och för att man anser att visionerna ger god mening snarare än av tvång. Ledaren betonar också organisationens beroende av medarbetarnas kompetens.

- Det finns samtidigt begränsningar i ledarens ansvar för medarbetaren. Det är alltså inte frågan om ett omfattande paternalistiskt ansvar på samma sätt som i den tidigindustriella perioden och som fortfarande finns kvar i vissa delar av världen.

- Det är viktigt att som ledare våga ta risker men också ta ansvar om det går fel. Det vill säga inte vara allt för bekymrad att "tappa ansiktet". Ledaren ska heller inte vara självcentrerad eller eftersträva status (varken personlig eller för gruppen). Istället ska han eller hon uppvisa en hög grad av integritet.

- Ledaren ska uppmuntra till samarbete inom organisationen. Konsensus betonas, snarare än konkurrens och beslutsamhet.

Några av de karaktäriserande egenskaperna för det nordiska ledarskapet kan te sig något paradoxala och tvetydiga. En sådan är relationen mellan formalitet och flexibilitet, som i vissa avseenden kan uppfattas som motsatta. Även om det nordiska ledarskapet inte är särskilt formellt, bygger det ändå på outtalade regler och förgivettaganden som oreflekterat kan uppfattas motverka flexibilitet inom organisationerna. Flexibilitet $\mathrm{i}$ ett nordiskt perspektiv förefaller bygga på en hög grad av autonomi. Det innebär att den enskilde medarbetaren har betydande makt, inflytande och ansvar över sitt eget arbete, och
De nordiska organisationerna har ofta en platt organisationsstruktur. Ledarskapet kännetecknas av en hög grad av delegering av makt och ansvar. Organisationerna präglas ofta av en låg grad av formalitet, men samtidigt av en hög grad av informella regler och procedurer. Ledaren ska fungera som en slags coach, han eller hon ska inspirera och motivera medarbetare snarare än betona sin auktoritet. Ledaren förväntas lyssna till alla medarbetare i samband med beslutsfattande och implementering.

\footnotetext{
12 Rapporten behandlar nordiskt ledarskap. Detta är inte helt oproblematiskt då några av studierna refererar till skandinaviska länder, medan andra refererar till nordiska. I föreliggande rapport går de samlat under begreppet "nordiska" då skillnaderna i de flesta fall är små.
} 
Enligt Globe-studien är ledarstilen i de latinamerikanska och anglosaxiska klustren nörmast den nordiska. att organisationen är decentraliserad och platt. Vidare förutsätter flexibilitet ett regelverk som inte är stramt och bindande.

En annan relation som kräver reflektion är den mellan individualism och kollektivism. Att forskningen pekar ut Norden som individualistiskt kan komma oväntat utifrån en allmänt förekommande uppfattning om nordbor som kollektivistiska. I en studie om svenskt ledarskap konstateras att om man separerar de två parametrarna (individualism-kollektivism) mellan en familjeoch en annan mer samhällelig dimension, visar det sig att man får höga nivåer för familjemässig individualism, medan man samtidigt hamnar högt i kollektivistiskt avseende vad gäller samhällsdimensionen. ${ }^{13}$ I en individualistisk kultur (i detta sammanhang) förväntas individen ta hand om sig själv, medan man i en kollektivistisk kultur förväntar sig starkare lojalitet till familj, släkt, arbetsgivare eller sitt övriga nära nätverket. Den viktigaste relationen, i termer av försörjningstrygghet, har man som individ i de nordiska samhällena på många sätt med välfärdssamhället. Det innebär att den typ av relationer som man i många andra delar av världen är beroende av (familj, arbetsgivare, nätverk etc.) är nedtonade i ett nordiskt sammanhang.

Det är också viktigt att den nordiska individualismen inte ska uppfattas på samma sätt som den amerikanska, vilken i högre utsträckning sker i konkurrens med andra personer (se exempelvis USA:s stapel för maskulinitet i figur 1), snarare är samarbete på arbetsplatsen en grund för den nordiska ledarskapsstilen och arbetsorganisationen.

En avslutande osäkerhet gäller i vilken utsträckning det nordiska ledarskapet är omtänksamt mot sina medarbetare. Å ena sidan pekar flera av de relaterade studierna mot att en ledare i Norden endast ansvarar för vad som är överenskommet i kontraktet, men inte mer än detta. Å andra sidan pekar studier mot att det nordiska ledarskapet är mer omtänksamt mot sina anställda. ${ }^{14}$ Sannolikt ska det tolkas som att arbetsgivaren i utbyte mot betydande ansvar ger sina medarbetare betydande makt vad det gäller sådant som arbetstider, var man arbetar (exempelvis hemifrån) etc. jämfört med andra länder. ${ }^{15}$ Det ger möjlighet att hantera sådant som barnhämtning, tandläkarbesök etc.

\section{Global jämförelse}

Som nämnts finns en forskningstradition där man ser på ledarskap, värderingar och kultur. Inom denna forskning finns ofta en ambition att skapa kulturella kluster som kan jämföras med varandra. Intressant är därför också att se hur det nordiska ledarskapsstilen placerar sig i relation till övriga kulturella kluster runt om i världen. En av studierna - Globe-studien - pekar exempelvis ut tio sådana i världen. ${ }^{16}$ Nedanstående diagram illustrerar hur de nordiska länderna placerar sig i relation till övriga globala kluster.
13 Holmberg \& Åkerblom, "Primus inter pares": leadership and culture in Sweden (1998).

14 Lindell \& Arvonen, "The Nordic Management Style in a European Context", i International Studies of Management and Organization 26:2 (1996).

15 Nordiska ministerrådet, Flexible work arrangements: The Nordic Gender Effect at Work (2018).

16 http://globeproject.com/results/clusters/nordic-europe?menu=cluster. 
Norden:

Danmark, Finland, Sverige

Anglo:

Kanada, USA, Australien, Irland, England

Sydafrika, Nya Zeeland

Germanska länder:

Österrike, Nederländerna, Schweiz, Tyskland

Latineuropa:

Afrika:

Zimbabwe, Namibia, Zambia, Nigeria

Östeuropa:

Ryssland, Georgien, Grekland, Kazakstan

Mellanöstern:

Turkiet, Kuwait, Egypten, Marocko, Qatar

Konfucianska länder:

Singapore, Hongkong, Taiwan, Kina,

Sydkorea, Japan

Sydostasien:

Filippinerna, Indonesien, Malaysia,

Indien, Thailand, Iran

Latinamerika: Ecuador, El Salvador, Colombia,

Bolivia, Brasilien, Guatemala, Argentina, Costa

Rica, Venezuela, Mexiko
Israel, Italien, Spanien, Portugal, Frankrike

Ungern, Albanien, Slovenien, Polen,

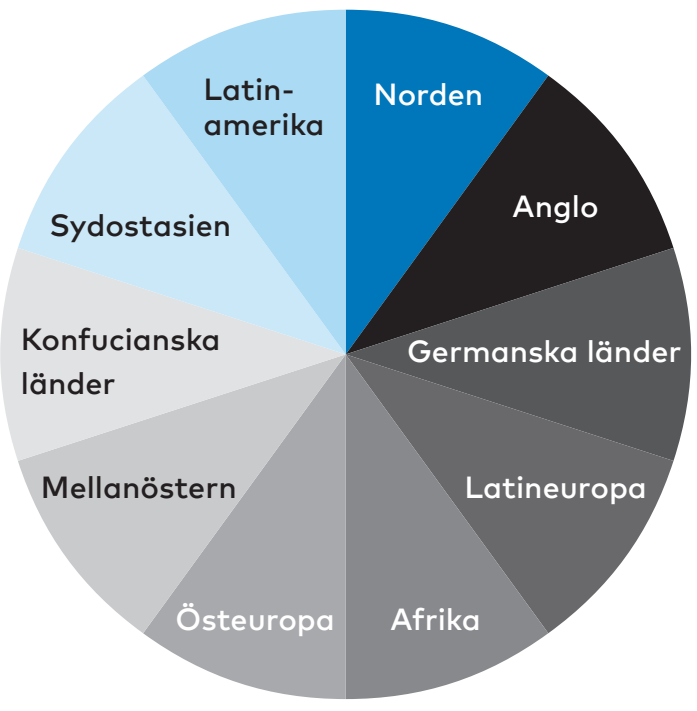

De kluster som globalt befinner sig närmast det nordiska är det anglosaxiska och det latinamerikanska. Mellanöstern och Afrika söder om Sahara har i studien klassificerats som markant annorlunda än den nordiska ledarskapsstilen. Längst från den nordiska ledarskapsstilen är ändå den östeuropeiska. ${ }^{17} \mathrm{En}$ östeuropeisk enastående ledare i Globe-studien sammanfattas som en person som är någorlunda karismatisk och lagorienterad, men som föredrar att vara oberoende och som bara i begränsad omfattning önskar involvera medarbetare. Han eller hon ägnar sig vidare åt självskyddande beteenden, om det ses som nödvändigt. ${ }^{18}$

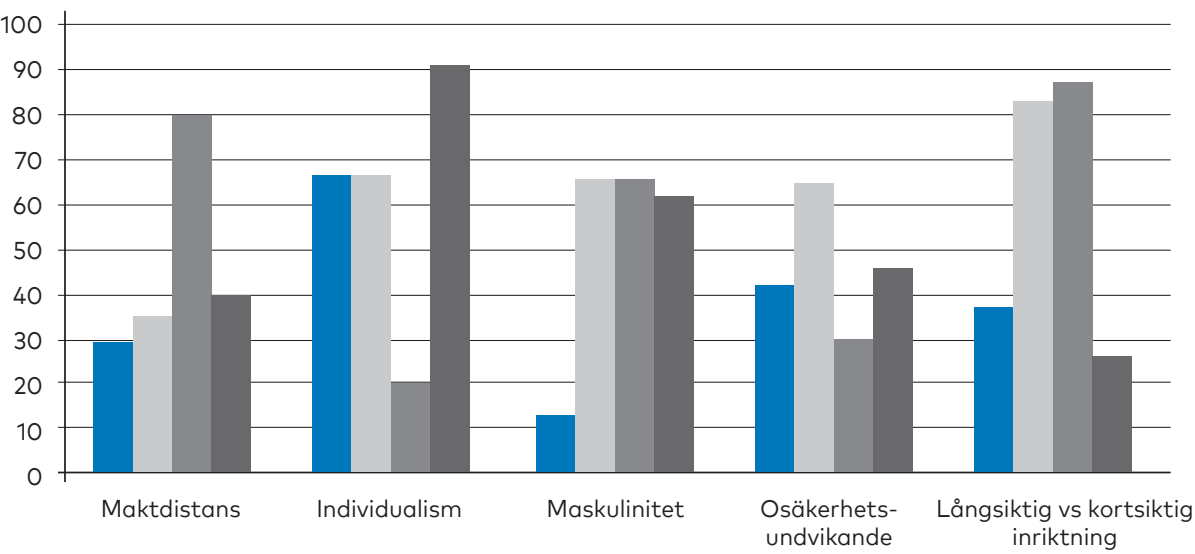

Diagrammet i figur 2 härstammar från Hofstedes forskning, som påminner om Globe-studien, men de har olika men samtidigt inte helt väsensskilda dimensioner. Exempelvis finns det beröringspunker mellan det som i Globe-studien benämns "team-oriented" med två av dimensionerna hos Hofstede: individualism-kollektivism och maskulinitet-femininitet.
Figur 1:

Landskluster enligt

Globe

Källa: House et al. (red.),

Culture, Leadership,

and Organizations:

The GLOBE Study of 62

Societies. (2004).

Figur 2:

Hofstedes kulturella dimensioner

Källa: https://www. hofstede-insights.com/ country-comparison.

Norden

Tyskland

Kina

USA 
Jämfört med Kina, USA och Tyskland står Norden ut genom lågt maktavstånd och låg nivå av maskulinitet.

Det finns skillnader mellan ledarskapsstilar i de nordiska länderna.
I diagrammet har ett medelvärde för Norden räknats ut i de olika dimensionerna. Detta har sedan satts i relation till utfallet för några andra slumpvist utvalda länder. Syftet är att visa hur Norden framstår i en internationell jämförelse, i detta fall i jämförelse med Tyskland, Kina och USA.

Med maktavstånd (power distance) avses den omfattning som mindre inflytelserika medlemmar inom en organisation accepterar att makten fördelas ojämnt och att deras röst har mindre betydelse. Med osäkerhetsundvikande (uncertainty avoidance) menas i vilken utsträckning en organisation bygger upp regler och förfaranden för att mildra oförutsägbarheten i framtida händelser. Maskulinitet (masculinity) representerar en preferens för prestation, hjältemod, beslutsamhet och materialistiska belöningar för framgångar. Dess motsats femininitet (femininity) står för en preferens för samarbete, blygsamhet, omvårdnad av de svaga och livskvalitet. Motsatsparet kan också beskrivas som att samhället, såsom i det första fallet, är mer konkurrensbenäget eller, såsom i det andra fallet, mer konsensusorienterat.

Som framgår av diagrammet ovan står Norden ut i jämförelse med Tyskland, Kina och USA genom att ha lågt maktavstånd och låg maskulinitet (eller hög femininitet, om man så vill).

\section{Skillnader mellan de nordiska länderna}

Det som benämns som en nordisk ledarskapsstil givetvis har nationella variationer mellan de nordiska länderna, vilket kan konstateras i utfallen i de olika studierna. Två av de mest utmärkande danska kännetecknen är exempelvis ytterst litet maktavstånd, så en strävan efter att utjämna fördelningen av makt, samt betoning av beroendet av medarbetare. Finsk ledarskapskultur framstår mer inriktad på konkurrens, prestation och materiell belöning, men samtidigt med lägre grad av formalitet. Den svenska ledarskapsstilen kan beskrivas som något öppnare för förändringar, men också mer formell i relation till regler och procedurer än övriga i Norden. I Norge betonas ett starkare beroende av medarbetare. Norge står kanske ännu mer ut för sitt framhävande av lagarbete. Island har inte lika höga nivåer av individualism som i övriga Norden men en högre grad av beroende mellan ledarskap, medarbetare och andra omkringliggande aktörer. ${ }^{19}$
19 https://www.hofstede-insights.com/country-comparison. För vidare studier om skillnader, se Smith et al., "In search of Nordic management styles", i Scandinavian Journal of Management 19 (2003); Warner-Söderholm, "But we're not all Vikings! Intercultural Identity within a Nordic Context", i Journal of Intercultural Communication 29 (2012); Warner-Söderholm \& Cooper, "Be Careful What You Wish for: Mapping Nordic Cultural Communication Practices \& Values in the Management Game of Communication", i International Journal of Business and Management 11 (2016). 


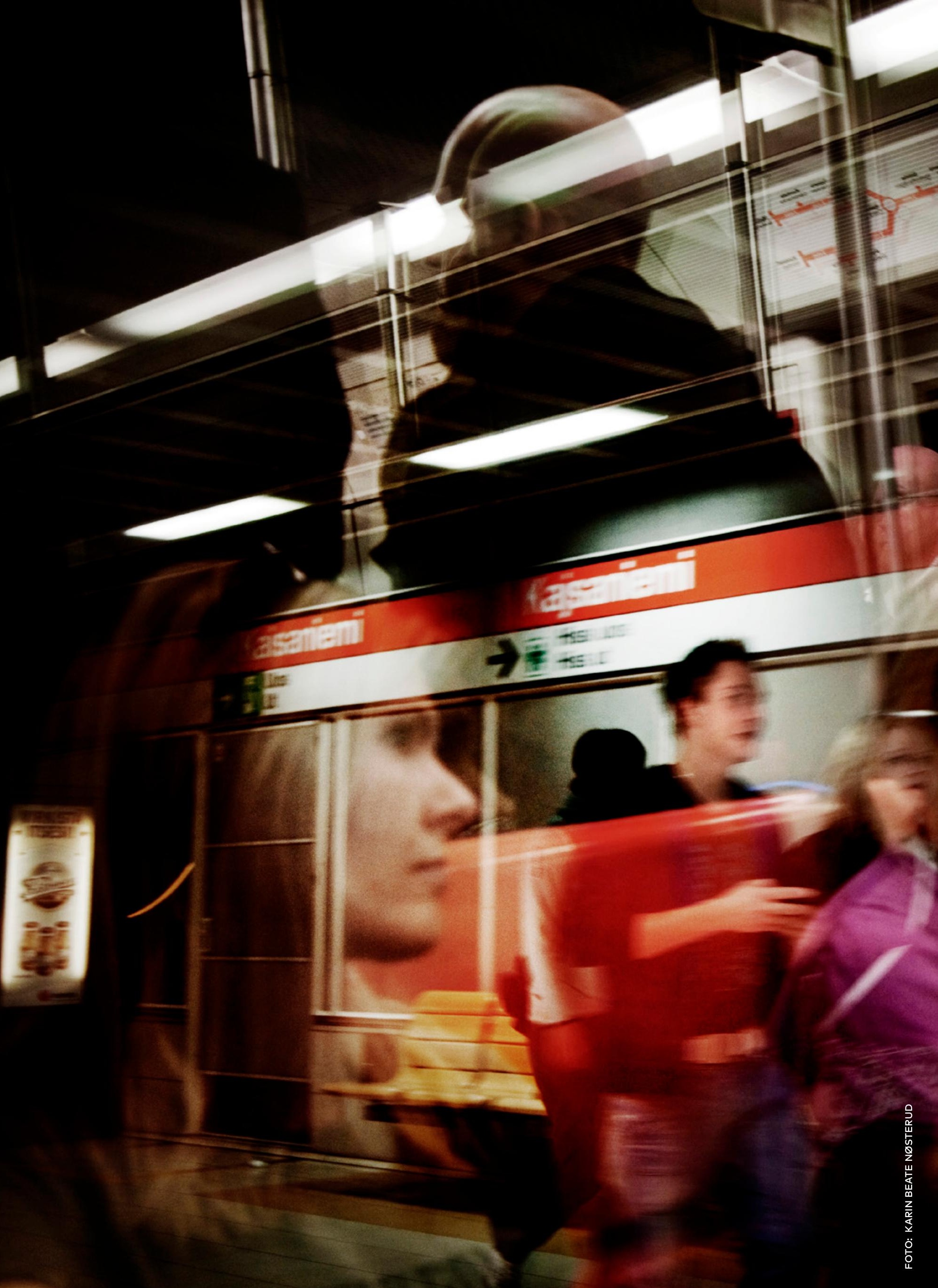




\title{
Ledarskapets rötter och framväxt
}

\author{
Varför är det nordiska ledarskapet ändå så pass homogent? Det kan bland \\ annat förklaras av att det funnits en aktiv överföring av tankemodeller kring \\ ledarskap mellan de nordiska länderna. ${ }^{20}$ En mer betydelsefull överföring har \\ sannolikt skett genom att nordiska företag som beslutat sig för att bli inter- \\ nationella, vanligen först blivit nordiska. ${ }^{21}$ Dessa förklaringar utgör sannolikt \\ bara en liten del av svaret. Istället handlar det om att se ett ledarskap som \\ en manifestation av värderingar, som utvecklas i relation till det omgivande \\ samhället.
}

Individer blir omedvetet inpräntade med om uppfattningar hur en ledare ska vara. Ledarskap blir på så sätt en manifestation av värderingar i samhället.
Det finns en forskningstradition kring ledarskap som utgår från att individer gradvis och omedvetet blir inpräntade med värderingar och föreställningar om hur en ledare ska uppföra sig och vilka karakteristika en ledarperson ska inneha. I en större grupp - företag, organisation, samhälle etc. - delar man implicit värderingar och föreställningar om hur ett ledarskap ska vara. ${ }^{22}$ I denna rapport pekas på två faktorer: den nordiska välfärdsstatens utformning samt traditionen av att balansera olika samhällsintressen. Detta kompletteras med ett perspektiv som pekar mot industristrukturen.

\section{Vålfärdsstatens uppbyggnad}

Efter 1900 började det paternalistiska systemet i Norden gradvis att minska i betydelse. Istället kan man se en successiv överföring av uppgifter från företagen till den offentliga makten, i första skedet till kommunerna. ${ }^{23}$ Med början efter andra världskriget utvecklade flertalet nordiska länder en regim med inslag av industriell planering och omfördelning genom välfärdsstaten. ${ }^{24}$ Ledande nordiska politiker - företrädesvis socialdemokrater - uppfattade därigenom att det inte fanns något behov av förstatligande av företagen, vilket varit en tidigare ambition hos många socialdemokratiska partier. Arbetstagarna skulle istället bli mindre avhängiga av företaget och istället ha sitt viktigaste beroende till välfärdsstaten. ${ }^{25}$

\footnotetext{
20 Se exempelvis Fellman, "Finska företagsledare möter svensk modernitet. Modeller för arbetets modernisering och ledning 1930-60.", i Houltz et al. (red.), Arbete pågår - i tankens mönster och kroppens miljöer (2008). Även i Byrkjeflot et al. (red.) (2001) återfinns exempel på överföring av ledarskap.

21 Inte sällan går det genom direktinvesteringar (FDI) i företag i ett annat nordiskt land. Fellman et al. (red.) (2008).

22 Samlande för denna forskning är att den vill fånga ett samhälles "auktoritetsstruktur" genom att studera ledarskap ur ett brett samhällsperspektiv. Det finns också ett annat begrepp som använts inom forskningen, nämligen "implicit ledarskapsteori".

${ }_{23}$ Inte sällan förefaller det ha varit den elit som drev näringslivet som nu var engagerad i det lokala politiska beslutsfattandet och uppbyggandet av de kommunala institutionerna. Christiansen et al. (red.), The Nordic Model of Welfare. A Historical Reappraisal (2006). Se även Berggren, "Management Strategies among Industrial Leaders in Southern Sweden 1850-1930", in Byrkjeflot et al. (red., 2001). 24 Byrkjeflot i Byrkjeflot et al. (red. 2001).

25 Byrkjeflot, "Nordic Management: from Functional Socialism to Shareholder Value", i Czarniawska \& Guje (red.), The Northern Lights: Organization theory in Scandinavia (2003). Ett undantag var möjligen Sverige med sina storföretag som också behöll ett större socialt ansvar för sina anställda och deras familjer. Men utvecklingen var också i Sverige i princip densamma som i övriga Norden.
} 
Det är ändå en förenkling att på ett enkelt sätt koppla samman den nordiska välfärdsmodellen med arbetarrörelsen, bland annat utifrån att modellen brukar ses som något som förenade såväl socioekonomiska grupper som partier. De nordiska samhällena under 1900-talet har ofta ansetts eftersträva en balans mellan traditionella värderingar och moderna visioner, liksom mellan olika politiska ståndpunkter, som inte nödvändigtvis var motsatta. En ofta förekommande - och möjligen något klichéaktig - beskrivning har varit som en blandning av kapitalistisk och socialistisk uppbyggnad ${ }^{26}$, där staten i de nordiska länderna tog på sig en större roll än vad som varit fallet för de flesta andra jämförbara länder.

Ett viktigt kännetecken för de nordiska välfärdssamhällena har varit synen på individen. Få välfärdsstater har på samma sätt som de nordiska konsekvent byggts upp kring individuell autonomi. De flesta välfärdssystem är kopplade till den enskilde individen, snarare än till familj och arbete, vilket är vanligt i andra liknande länder. "Statsindividualism" har använts som teoretiskt begrepp för att fånga en nordisk välfärdsregim som inte är uppbyggd "på det ömsesidiga beroendet utan på autonomins fasta grund". ${ }^{27}$

Detta har även satt avtryck i ledarskapsstilen. På ett djupare plan handlar individualismen om att den enskilde inte har ett starkt beroende till arbetsgivaren för sin existens, och dessutom mindre (materiellt) behov av sociala nätverk än i andra delar av världen. ${ }^{28}$ Detta har minskat status för ledaren och tvingat ledaren att fungera som coach, snarare än som en auktoritär ledare.

En nordisk ledare måste således förhålla sig till att inte kunna förvänta sig att medarbetaren uppfattar sig som starkt beroende av arbetsgivaren eller -platsen. Sannolikt är det en drivkraft bakom den platta organisationsstrukturen.

\section{Att balansera intressen}

Ett annat viktigt utvecklingsdrag i Norden då man rör sig en bit in i 1900-talet har varit fredlig konfliktlösning, inte minst inom arbetsmarknaden. Detta har också kommit att sätta sin prägel på modern lagstiftning (arbetsrätt, skiljedomstolar). Balanseringen av olika intressen framgår tydligast av hur man i Norden organiserat arbetsmarknaden, med fria obundna parter (fack och arbetsgivare) och staten - ibland benämnd som ett trepartssystem. Återkommande förhandlingar och konfliktlösning har byggt upp en stor del av tilliten mellan centrala aktörer i de nordiska samhällena. ${ }^{29}$ Strävan efter balans har bland annat lett fram till att arbetstagarrepresentanterna även har representation i styrelserna för de nordiska företagen. ${ }^{30}$

\footnotetext{
26 Fellman et.al (red.), Creating Nordic Capitalism. The business History of a Competitive Periphery (2008), 559.

27 Citat hämtat från Berggren \& Trägårdh, Är svensken människa? Gemenskap och oberoende $i$ det moderna Sverige, s. 10 (2006). Boken har många referenser till den nordiska utvecklingen (där man också pekar på några historiska skillnader mellan länderna).

28 För ett exempel på ett mer paternalistiskt förhållningssätt till ledarskap hämtat från Indien hänvisas till Sharma, "Corporate Rishi Leadership Model: An Indian Model for Corporate Development \& Ethical Leradership", i Pareek et al. (red.), Human Resource Development in Asia (2002).

29 Fellman et al. (2008), 560. För en diskussion om tillitens roll i de nordiska samhällena, se Andreasson, Tillit - det nordiska guldet (2017).

30 Sianani et al., "Corporate Governance in Scandinavia: Comparing networks and formal institu-
} tions", i European Management Review 5(1) (2008).
Välfärdsstaten i nordisk tappning har skapat ett mindre beroende till arbetsgivaren för den anställde. Detta har minskat statusen för ledaren och skapat behov av att ledaren snarare ska fungera som coach. Det är sannolikt också en drivkraft bakom den platta organisationsstrukturen. 
Strävan i de nordiska

länderna att balansera

samhällsintressen har

sannolikt medfört att

ledarrollen inte har sam-

ma status som i andra

länder. Det förstärker

också rollen som coach

snarare än auktoritär

ledare. Men inte minst

kommer strävan efter

konsensus och samarbe-

te från balanssträvan-

dena.
Balanseringen av intressen har också varit ett tema i de nordiska ägarstyrningsmodellerna. En fundamental princip för modern nordisk ägarstyrning av börsnoterade företag har - till skillnad från andra delar av världen - varit principen att ge aktieägarmajoriteten möjligheter att kontrollera företaget. Som en konsekvens har bland annat ägarna intagit en mer aktiv roll - inte minst är man mer aktiv i styrningen av bolaget. Samtidigt får ägarminoriteten skydd mot missbruk av majoritetens makt genom ett välutvecklat system för skydd av ägarminoriteter. ${ }^{31}$

Effekterna av strävan att balansera intressen har sannolikt blivit att ledarrollen inte har samma status som i många andra länder, och att ledaren fungerar som en coach för medarbetarna, vilka i hög grad är självgående. Individualismen inom välfärdsstaten och intressebalanseringen förstärker således varandra i detta avseende.

De höga nivåerna av konsensus och samarbete, vilka pekats ut som viktiga kännetecken för det nordiska ledarskapet, härrör troligen också från strävan att balanser intressen. Vi kan, sannolikt utifrån samma aspekter, också härleda de höga nivåerna av ansvarstagande och tillit inom organisationerna.

\section{Avancerad produktion nära de globala marknaderna}

Norden industrialiserades relativt sent. Perioden från dess genombrott omkring 1870 fram till första världskriget kännetecknas av att man i Norden - liksom i stora delar av den värld i övrigt som påbörjat industrialisering - expanderade exportindustrin. I Finland, Norge och Sverige var skogs- och skogsprocessindustrin viktigast, medan det i Danmark var jordbruksprodukter som kom att ha den viktigaste positionen. För Islands del var det snarare fiskeindustrin som utvecklades under slutet av 1800-talet och ännu mer markant efter inledningen av 1900-talet. Exportindustrin i Norden, som redan från den tidiga industrialiseringen var politiskt prioriterad, lyckades även successivt höja sig i värdekedjan och med tiden också exportera mer avancerade produkter. ${ }^{32}$

För länder som de nordiska, vars tillväxt är beroende av export, är inte bara utvecklingen av den nationella ekonomin, utan även förändringar i den internationella ekonomin särskilt viktiga - så var det på 1890-talet och än i dag.

1900-talets utveckling kom att präglas av, å ena sidan, en del kriser såsom mellankrigstidens djupa depression, oljekrisen i början av 1970-talet och den höga arbetslösheten i slutet av århundradet. Dessa hade en omfattande negativ inverkan på många individer och företag liksom på de nordiska samhällena i stort. Å andra sidan har perioden i dess helhet utmärkts av ett väldigt gott resultat för ekonomin i Danmark, Finland, Island, Norge och Sverige. Inte minst har exportindustrin firat stora framgångar. Den har också varit föremål för omfattande politisk uppmärksamhet i länderna.

31 Lekvall (2014). Studien menar att minoritetskyddet kanske inte är unikt för Norden, utan existerar också i övriga Europa. Men de olika delarna av systemet tillsammans skapar något unikt som dessutom är effektivt som motvikt till den maktkoncentration som ägarstyrningsmodellen ger till majoritetsägare.

32 Myklebust, "The Politics of Organization and Management", i Byrkjeflot et al., The Democratic Challenge to Capitalism. Management and Democracy in the Nordic Countries (2001), 356. 
Det nordiska näringslivet har visat stor förmåga att ställa om och förnya sig. Näringslivet har också klarat omställningen till ett starkare inslag av tjänsteproduktion. Detta kom att ske under andra hälften av 1900-talet, parallellt med genombrottet för en mer specialiserad och kunskapsintensiv produktion i mindre enheter. I ett nordiskt ledarskapsperspektiv framstår SAS vd Jan Carlzons bok Riv pyramiderna i mitten av 1980-talet som en milstolpe. ${ }^{33}$ På många sätt var boken, eller snarare manifestet, ett försök att göra SAS till ett mer kundorienterat företag. Istället för de hierarkiska strukturer som Carlzon menade hade präglat samhället sedan feodal tid var det dags för ett mer horisontalt perspektiv där makt försköts åt dem som i första hand träffade kunderna. Det var betydligt effektivare att låta personen längst ut i förgreningen i större utsträckning fatta beslut utifrån kunskap och erfarenhet.

Även om det fortfarande finns band till de näringar som präglade den första industrialiseringsfasen har de nordiska länderna idag differentierat sina ekonomier. Inte minst kan man se nordiska framgångar inom några av de mest värdeskapande segmenten i de globala värdekedjorna: IKT, energisektorn och livsvetenskap, för att nämna några. Idag hör Norden till den globala tätklungan när det gäller tillväxt, produktivitet och innovation.

Utvecklingen har också medfört att det finns betydande skillnader mellan industri- och näringsstruktur mellan länderna i Norden. Exempelvis präglas svenskt näringsliv av, sett till landets storlek, väldigt stora företag. I den andra änden av skalan finns Danmark med många små och medelstora företag. De nordiska länderna har dock gemensamt att de kan karaktäriseras som små, öppna ekonomier med fokus på internationell handel nära de internationella marknaderna.

Detta har sammantaget bland annat skapat behov för anpassningsförmåga. Det innebär vidare att dem man leder har en hög utbildningsnivå och stark identitet i det arbete man utför. En konsekvens av detta är flexibilitet inför förändringar som bygger på att ledaren ansvarar för att peka ut en långsiktig riktning för de på många sätt självgående medarbetarna. (Det har i viss forskning beskrivits som att nordiska ledare ska vara karismatiska.) Medarbetarna har därigenom fått betydande ansvar och makt.
Att Norden har små, öppna ekonomier med fokus på internationell handel har medfört ett behov av anpassningsförmåga och att organisationerna präglas av flexibilitet. Ledaren måste även kunna vara visionär och kunna peka ut en riktning för relativt självgående medarbetare.

зз Carlzon, Riv pyramiderna! en bok om den nya människan, chefen och ledaren (1985). 


\section{Sammanfattning, utfall och kritik}

I korthet kan det nordiska ledarskapet beskrivas som hög grad av delegering av makt och ansvar inom platta organisationer. Ledaren ska uppmuntra till samarbete. Vidare har Norden mindre formalitet i organisationerna men samtidigt hög grad av informella regler och procedurer. Han eller hon ska fungera som ett slags coach, inspirera och motivera medarbetare snarare än att betona sin auktoritet. Han eller hon måste lyssna till alla medarbetare i samband med beslutsfattande och implementering av beslut. Det är också viktigt att våga ta risker och samtidigt ta ansvar om det går fel, det vill säga inte vara allt för bekymrad för att i arbetssammanhang "tappa ansiktet".

Om man ser närmare på samhällsutvecklingen i Norden under 1900-talet framstår kompromisser och önskan om att balansera olika intressen i samhället som ett genomgående drag. De nordiska samhällena kan sägas ha eftersträvat balanspunkter för aktörer med närmast motstående intressen, särskilt inom arbetsmarknadsområdet där arbetsmarknadens parter fått ett centralt ansvar. I texten pekades även ägarstyrningen av bolag som ett annat område där Norden fått en delvis annan balansering av intressen jämfört med övriga världen. Den verkställande direktören och det övriga ledarskapet inom företaget har i Norden exempelvis getts en roll som fokuserar mer på interna förhållanden - med mer begränsad makt än i andra länder. De sammanlagda konsekvenserna av detta har sannolikt blivit att ledarrollen inte har samma status som i många andra länder, och att ledaren fungerar som en coach för medarbetarna, vilka i hög grad är självgående.

Strävan efter balans kan vidare kopplas till sådant som konsensus och samarbete, vilka pekats ut som viktiga kännetecken för det nordiska ledarskapet. Vi kan, sannolikt utifrån samma aspekter, också härleda de höga nivåer av ansvarstagande och tillit inom organisationerna.

Ett annat drag gäller välfärdsstatens uppbyggnad i Norden. Det tidiga paternalistiska förhållandet mellan arbetsgivare och arbetstagare kom en bit in på 1900-talet att luckras upp och ersättas med en relation mellan arbetstagaren och välfärdsstaten. Det har påpekats att den nordiska välfärdsmodellen har en stark individualistisk dimension. (Vi kunde också i några av de redovisade studierna se en komplicerad relation i Norden mellan individualism och kollektivism.) Detta har troligen även gett avtryck i ledarskapsstilen. Att den anställde inte ser sig som beroende av arbetsgivaren, på samma sätt som är fallet i övriga världen, är en drivkraft bakom den "platta" organisationsstrukturen. Det förstärker också bilden av ledaren som icke-auktoritär.

Ett tredje drag gäller industristrukturen. Om man förlägger det initiala industriella genombrottet i Norden till omkring slutet av 1800-talet, kan man redan i den tidiga fasen notera några drag som kommit att utmärka den industriella strukturen i Norden ända fram till våra dagar. Norden består av relativt små och öppna ekonomier nära de globala marknaderna. De är också kunskapsintensiva ekonomier som befinner sig i framkanten av den tekniska utvecklingen. Följderna blir att ledare måste säkerställa att det finns god omställningsförmåga inom organisationerna, inte minst genom att peka ut långsiktiga mål. 
Den nordiska ledar-

skapsstilen kan beskri-

vas som ett sätt att

kombinera ekonomisk

tillväxt med demokratisk stabilitet.

Det har riktats viss

kritik mot den nordiska

ledarskapsstilen. En del

av kritiken handlar om

att den mest hante-

rar personalfrågor och

administration. Besluten

fattas inom andra delar

av organisationen.
En forskare menar att det som gör det meningsfullt att tala om en specifik nordisk ledarskapsmodell är dess strävan att kombinera ekonomisk tillväxt med demokratisk stabilitet. ${ }^{34}$ Utifrån genomgången i denna rapport är det en beskrivning som ger god mening.

Man kan föreställa sig att det är enkelt att vara ledare i Norden, med tanke på självgående, flexibla och kunniga medarbetare som inte behöver detaljstyras. Men en sådan beskrivning underskattar komplexiteten i den nordiska ledarskapsstilen. Det är sannolikt betydligt svårare att leda en sådan organisation, med avancerad produktion och med starka, självgående medarbetare som inte vill beordrade utan drivas genom motivation, jämfört med ett ledarskap som vilar på auktoritet.

Det är inte svårt att tillerkänna den nordiska ledarskapsstilen ett betydande värde för dess förmåga att å ena sidan skapa förutsättningar för produktivitet och tillväxt, särskilt i organisationer med hög kunskapsnivå, och å andra sidan ha hög trivsel och god arbetsmiljö. ${ }^{35}$ Nordiska företag får också höga poäng vad gäller innovationsförmåga. ${ }^{36}$ Ett annat positivt utfall är att omkring 60 nordiska företag återfinns på Forbes lista över världens 2000 största företag, vilket är fler än Tyskland, vars ekonomi är större än den samlade nordiska. ${ }^{37}$ Exemplen kan utökas men visar på samma sak, nämligen de framgångar som nordiska företag upplevt. Detta har inte bara med ledarskapet att göra, men ledarskapet har med all sannolikhet varit en viktig del i denna positiva utveckling. ${ }^{38}$

Det har även riktats kritik mot den nordiska ledarskapsmodellen, bland annat uppfattas den av vissa som närliggande begreppet "ledarlös demokrati" (leaderless democracy). Många av besluten fattas på andra platser inom organisationen eller uppfattas som "givna", och ledarskapet handlar till stor del om administration samt personalfrågor. Att avgöra vad det är som ska göras och hur är exempel på överväganden som många medarbetare förväntas kunna ta ansvar för på egen hand. Erfarenhet, professionellt omdöme eller en kollegas synpunkter gör på så sätt stora sjok av traditionell arbetsledning mer eller mindre överflödig. Den norske samhällsekonomen Torger Reve har argumenterat för att den nordiska ledarskapsmodellen kommit att bli alltför internt fokuserad och huvudsakligen upptagen med att skapa en rättvis fördelning. Det kan i sin tur skapa passivitet, inte minst i en global affärsmiljö som kräver konstant förändring. Det finns även en tendens att ett sådant ledarskap flyr från ansvar. ${ }^{39}$ En annan kritik gäller nordiska företags avsaknad av tydliga hierarkier, vilket kan bli problematiskt i andra länder. Några som nämnts är Frankrike, Kina samt länder i Central- och Östeuropa. ${ }^{40}$
34 Kallenberg, "Nordisk ledelse og økonomisk kultur i et internasjonalt perspektiv", i Institutt for Sosiologi (Rapport 30, 1993); Katzenstein, Small States in World Markets (1985).

35 Larsen \& de Neergard, Nordic Lights. A research project on Nordic leadership and leadership in the Nordic countries, 34-37 (2007).

36 Se exempelvis Bloomberg 2018 Innovation Index.

37 Lekvall (2014).

38 Exempelvis utnämnde Harvard Business Review år 2016 verkställande direktören för Novo Nordisk, Lars Rebien Sørensen, till världens bästa ledare. https://hbr.org/2016/11/the-best-performingceos-in-the-world. Ett specifikt område där man kan se en effekt från den nordiska ledarskapsstilen är kvalitet. Høie, Ethical Management. Creativity, Sustainability, Governance (2018).

39 Reve, "Scandinavian Management - from competitive advantage to competitive disadvantage" i Tidsskrift for Samfunnsforskning 35:4 (1994)

40 Smith et al. (2003). 


\section{Nordiskt ledarskap inför framtiden}

Vi upplever idag ett tekniskt skifte som i grunden kan komma att förändra samhället, ekonomin, förutsättningarna för företagande, arbetsorganisation och inte minst ledarskapet. Mängden information som finns tillgänglig, hastigheten på sönderspjälkning av gamla modeller och accelerationen av innovationer är i dagsläget svår att förutspå. Begreppet "den fjärde industriella revolutionen" är redan väletablerat. Den pågående digitaliseringen har lett till att allt fler så kallade smarta fabriker rullar igång med intelligenta maskiner. De hanterar både massproduktion och skräddarsydda beställningar i liten upplaga. Onekligen kommer detta att leda till behov av en utveckling av ledarskapsrollen, såväl i Norden som på många andra ställen.

De flesta av de strukturella faktorer som varit viktiga för framväxten av en särskild ledarskapsstil är fortfarande aktuella i de nordiska samhällena: partssystem på arbetsmarknaden, välfärdsstatens struktur och ett exportinriktat och kunskapsintensivt näringsliv. Ur det perspektivet kommer förändringarna sannolikt att balanseras av nordiska traditioner. Det kan ändå vara på sin plats att fånga upp några aspekter som kan sägas ligga vid sidan av det förda resonemanget men som är centrala för det nordiska ledarskapets framtid.

För det första har företagen i de nordiska samhällena en annan roll jämfört med stora delar av världen, i synnerhet i jämförelse med amerikanska företag. I Norden har företagen en närmare och mer symbiotisk relation till det omkringliggande samhället än de amerikanska motsvarigheterna. Det inkluderar inte minst en annan syn på ansvarstagande. Företagens ansvar kan beskrivas på olika sätt. Gemensamt är att det handlar om att vårda relationerna till sina intressenter (stakeholders). Intressenterna kan vara av olika typer. Några har starkt inflytande, till och med avgörande för företagets överlevnad. Hit hör exempelvis anställda, kunder och leverantörer. Andra kan ha mer övergripande inflytande och återfinns bland media, myndigheter, fackföreningar och närboende. För nordiska företag är det viktigt att skapa förtroendefulla relationer till intressenterna. Om dessa relationer försämras eller försvagas, äventyras företagets fortsatta utveckling. Man kan i detta sammanhang, som kontrast mellan det amerikanska och nordiska synsättet, hänvisa till den amerikanske ekonomen Milton Friedmans berömda uttalande om att "the business of business is business". För ett amerikanskt företag är det viktigaste samhällsansvaret att gå med vinst.

För det andra finns det en etisk dimension i kärnan av den nordiska ledarskapsstilen. Den berör djupgående överväganden om hur man ser på exempelvis demokrati, människovärde, ansvar, plikt, rättigheter, individens roll i förhållande till kollektiv etc. Att långsiktigt främja en etisk dimension i den nordiska ledarskapsstilen kan likställas med att understödja centrala grundvärderingar i våra samhällen. De värderingar som hittills har väglett ledarskapsfrågor i Norden har särskilt gällt öppenhet, integritet och tillit. ${ }^{41} \mathrm{Om}$ en organisation misslyckas med att leva upp till dessa värderingar blir konsekvenserna många gånger större i Norden än i andra delar av världen (där möjligen andra värderingar har betydelse).
I Norden betonas starkare än i andra delar av världen vikten av att företagen har ansvarsfulla relationer till omgivande aktörer och samhälle.

De värderingar som företrädesvis väglett det nordiska ledarskapet har varit öppenhet, integritet och tillit.

${ }^{41}$ För en utvidgad diskussion, se Høie (2018). 
Utbildning är på flera sätt nyckeln till den nordiska ledarskapsstilen.
För det tredje är utbildning på många sätt nyckeln till den nordiska ledarskapsstilen, dels i förståelsen att medarbetare tack vare vidareutbildning kan vara flexibla, vilket ger dem möjlighet att bland annat ta ett stort ansvar inom organisationerna, dels är utbildning också centralt ur ett annat perspektiv, nämligen att framtidens ledare vid universitet och högskolor studerar ledarskapsfrågor ur ett brett perspektiv och inte enbart - vilket ofta är fallet - ur ett amerikanskt ledarskaps- och arbetsorganisationsperspektiv, vilka, som nämnts, tenderar att prioritera kortsiktiga perspektiv i jämförelse med de nordiska.

Det är i samspelet mellan värderingsfrågor och praktiska överväganden som ledarskapet i Norden sannolikt kommer att utvecklas i framtiden. Det är därför betydelsefullt att kontinuerligt föra en diskussion om ledarskapets förutsättningar, uttryck och följder. 


\section{Bilaga: Några studier om ledarskap, värderingar och kultur}

Nedan genomgås två av de mest uppmärksammade studierna inom området "kultur, ledarskap och värderingar": de som gjorts av Geert Hofstede och den så kallade Globe-studien. Dessutom adderas här de studier som gjorts av Fons Trompenars, som handlar om tvärkulturell kommunikation. Gemensamt för dem är att studierna börjar på nationell nivå för att sedan skapa landseller samhällskluster där Norden är ett ofta förekommande kluster.

\section{Hofstede}

Nedan är ett försök till övergripande schematisering av de olika dimensionerna i Hofstedes analys:

\begin{tabular}{|c|c|}
\hline Dimension 42 & Definition \\
\hline $\begin{array}{l}\text { Maktavstånd } \\
\text { (power distance) }\end{array}$ & $\begin{array}{l}\text { Den omfattning som mindre inflytelserika med- } \\
\text { lemmar inom en organisation accepterar att } \\
\text { makten fördelas ojämnt och att deras röst har } \\
\text { mindre betydelse. }\end{array}$ \\
\hline $\begin{array}{l}\text { Osäkerhetsundvikande } \\
\text { (uncertainty avoidance) }\end{array}$ & $\begin{array}{l}\text { I vilken utsträckning en organisation bygger upp } \\
\text { regler och förfaranden för att mildra oförutsäg- } \\
\text { barheten i framtida händelser. }\end{array}$ \\
\hline $\begin{array}{l}\text { Maskulinitet vs feminitet } \\
\text { (masculinity vs. femininity) }\end{array}$ & $\begin{array}{l}\text { Maskulinitet representerar en preferens i sam- } \\
\text { hället för prestation, hjältemod, beslutsamhet } \\
\text { och materialistiska belöningar för framgångar. } \\
\text { Femininitet står för en preferens för samarbete, } \\
\text { blygsamhet, omvårdnad av de svaga och livskva- } \\
\text { litet. Motsatsparet kan också beskrivas som att } \\
\text { samhället, som i det första fallet, är mer konkur- } \\
\text { rensbenäget eller, som i det andra fallet, är mer } \\
\text { konsensusorienterat. }\end{array}$ \\
\hline $\begin{array}{l}\text { Individualism vs kollektivism } \\
\text { (individualism vs. collectivism) }\end{array}$ & $\begin{array}{l}\text { Individualism kan definieras som en preferens för } \\
\text { ett socialt ramverk inom vilket individer endast } \\
\text { förväntas ta hand om sig själva och sin nära } \\
\text { familj. I motsats till denna definition av individua- } \\
\text { lism representerar kollektivism en preferens för en } \\
\text { stark sammanhållning bland släkten eller en an- } \\
\text { nan social grupp: man förväntar sig att man inom } \\
\text { detta nätverk ser efter varandra, och är ovillkorligt } \\
\text { lojal gentemot gruppens medlemmar. Vidare anger } \\
\text { denna dimension huruvida individer agerar på } \\
\text { egna initiativ eller kollektivistiskt. I en individualis- } \\
\text { tisk kultur läggs stor vikt på individers kompetens } \\
\text { vid anställning, befordran, lönesättning etc. I en } \\
\text { mer kollektivistisk kultur betonar man istället den } \\
\text { enskildes bidrag till gemenskapen. }\end{array}$ \\
\hline $\begin{array}{l}\text { Långsiktig inriktning } \\
\text { (long-term orientation) }\end{array}$ & $\begin{array}{l}\text { Dimensionen beskriver ett samhälles tidshorisont, } \\
\text { den betydelse som läggs vid framtiden i jäm- } \\
\text { förelse med nutiden och det förflutna. }\end{array}$ \\
\hline
\end{tabular}

42 En sjätte dimension har senare adderats: Indulgence vs. Restraint. Denna har utelämnats i föreliggande rapport. 
Norden står särskilt ut i några av dimensionerna. Vad det gäller maktavstånd uppvisar Norden låga siffror, vilket alltså indikerar att i Norden finns en förväntan om att även personer på lägre positioner inom en hierarki har inflytande. (Danmark har exceptionellt låg siffra för maktavstånd.) Det innebär vidare att nordiska organisationer kan förväntas vara platta och decentraliserade med ett ledarskap som i första hand eftersträvar samarbete. ${ }^{43}$

Organisationer i de nordiska länderna präglas också av höga nivåer av femininitet eller låga grader av maskulinitet. I sådana länder tenderar ledarskap att präglas av konsensussökande och sympati för "den svaga", snarare än konkurrens.

Hofstede utmålar vidare Norden som en relativt individualistisk region (medelhög nivå). Det innebär att det är fokus på sådant som individuell kompetens i samband med lön, anställning etc. Samtidigt ses inte det bidrag den enskilde ger till gruppen som oväsentligt, vilket varit fallet om nivåerna hade varit ännu lägre.

I nedanstående dimensioner uppvisar Norden ett lite mer blandat resultat: I en långsiktigt inriktad kultur är det grundläggande begreppet att världen är i förändring, och förberedelser för framtiden alltid är nödvändiga. Norden uppvisar relativt låga nivåer av långsiktig inriktning - med undantag för Sverige, som har högre nivåer men samtidigt inte höga. Samhällen som uppvisar låga värden på denna dimension föredrar att behålla traditioner och normer, samtidigt som man betraktar samhällsförändringar med viss misstänksamhet. Man ser inte samma behov av att spara för framtiden och önskar snabba resultat. Samhällena har även en normativ hållning. Länder som Sverige uppvisar mer pragmatism.

Vad gäller osäkerhetsundvikande hamnar Sverige och Danmark på låga nivåer jämfört med det globala genomsnittet, medan övriga nordiska länder hamnar i närheten av mitten på skalan, vilket ska ses som att de saknar tydlig preferens. Det innebär att ledare i Sverige och Danmark opererar i en mindre formell miljö än ledare i de flesta andra länder, med ett mindre behov av strikta regleringar.

\section{Globe}

De sex dimensionerna i Globe-studien är:

\begin{tabular}{|l|l|}
\hline Dimension & Definition \\
\hline $\begin{array}{l}\text { Karismatisk/värdebaserad } \\
\text { (Charismatic/Value-based) }\end{array}$ & $\begin{array}{l}\text { Reflekterar förmågan att inspirera, motivera och } \\
\text { förvänta sig högpresterande resultat från andra } \\
\text { baserat på kärnvärderingar. }\end{array}$ \\
\hline $\begin{array}{l}\text { Grupporienterad } \\
\text { (Team-oriented) }\end{array}$ & $\begin{array}{l}\text { Betonar effektivt lagsamarbete (teambuilding) } \\
\text { och genomförande av gemensamma målsättning- } \\
\text { ar bland lagmedlemmar. }\end{array}$ \\
\hline $\begin{array}{l}\text { Delaktig } \\
\text { (Participative) }\end{array}$ & $\begin{array}{l}\text { Avspeglar den grad ledaren involverar andra i } \\
\text { fattande och genomförande av beslut. }\end{array}$ \\
\hline $\begin{array}{l}\text { Autonom } \\
\text { (Autonomous) }\end{array}$ & $\begin{array}{l}\text { Avser oberoende och individualistiska ledarskaps- } \\
\text { attribut. }\end{array}$ \\
\hline $\begin{array}{l}\text { Humanorienterad } \\
\text { (Humane-oriented) }\end{array}$ & $\begin{array}{l}\text { Reflekterar stöttande och omtänksamt ledarskap } \\
\text { och inkluderar medkänsla och generositet. }\end{array}$ \\
\hline $\begin{array}{l}\text { Självbeskyddande } \\
\text { (Self-protective) }\end{array}$ & $\begin{array}{l}\text { Fokuserar på att säkerställa individens och grup- } \\
\text { pens säkerhet genom statusförbättringar och inte } \\
\text { "tappa ansiktet". }\end{array}$ \\
\hline
\end{tabular}

43 https://www.hofstede-insights.com/country-comparison 


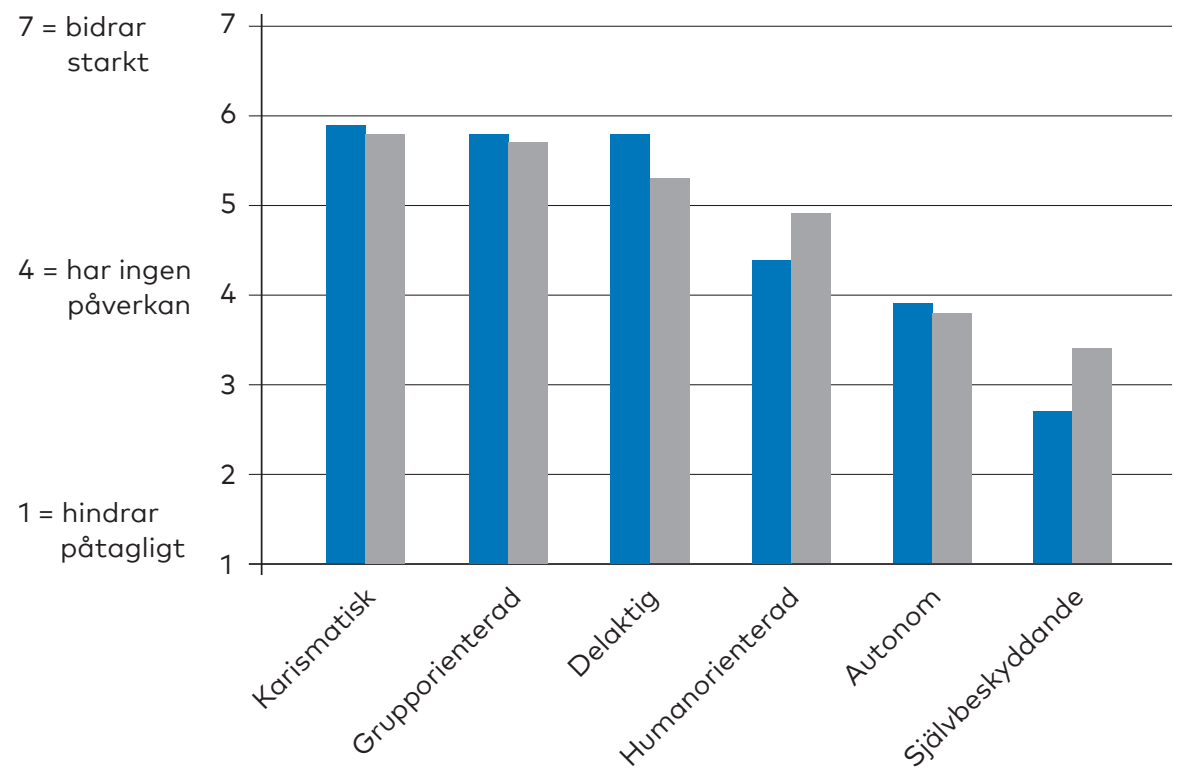

Utifrån utfallet grupperade man sedan de ingående länderna i tio kluster varav ett är nordiskt. ${ }^{44}$ Ovanstående diagram visar hur starkt olika dimensioner slår igenom i det nordiska ledarskapet och förhållandet till övriga världen.

Av studien framgår att det är särskilt i tre dimensioner som det nordiska klustret står ut mot övriga världen. Det första gäller delaktighet i ledarskapet. Det indikerar att det nordiska ledarskapet till högre grad än i övriga världen involverar andra i både beslutsfattande och implementering av beslut.

Ett signifikativt drag i det nordiska ledarskapet är att det värderar lågt skyddande av individ och grupp (självbeskyddande). Kanske är detta, enligt Globe-studien, det mest signifikanta vad gäller det nordiska ledarskapet. Det innebär att en nordisk ledare starkt ska undvika attribut och beteenden som att vara självcentrerad, statusmedveten, anstränga sig för att inte "tappa ansiktet" och ägna sig åt konfliktskapande beteenden. Låga värden, såsom det nordiska, ses som gynnsamt för effektiviteten i en organisation.

Vidare uppvisar det nordiska klustret låga värden vad gäller att vara humanorienterad, alltså i relation till andra ingående regionala kluster. Det innebär att det nordiska ledarskapet i en global kontext är mindre orienterat mot att vara "stöttande". Detta analyseras djupare i Globe-studien. Man tycks mena att detta kan sättas samman med hög materiell välfärd (möjligen också i kombination med en generös välfärdsstat), vilket gör att nordbor har mindre behov av sociala nätverk än i delar av övriga världen. ${ }^{45}$ Sannolikt kan det även sättas i relation till att Norden får relativt höga nivåer för "individualism" i Hofstedes studie.
Figur 3:

Utfall enligt

Globe-studiens sex

dimensioner mellan

Norden och ett globalt genomsnitt.

Norden

Genomsnittet
44 House et al. (2004). Se även Singh Chokar et al., Culture and leadership, across the world: The GLOBE Book of In-Depth Studies of 25 Societies (2007); Morsing, "Corporate Social Responsibility in Scandinavia - a turn towards the business case?", i May \& Cheney (red.), The Debate over Corporate Social Responsibility (2007); Tollgerdt-Andersson, Ledarskapsteorier, företagsklimat och bedömningsmetoder (1989)

45 House et al., 569 (2004). 
Nedanstående är dimensioner där Norden inte framstår så särpräglat jämfört med andra länder:

Det nordiska klustret har höga poäng vad gäller att vara grupporienterat, vilket förstärker bilden av hög nivå av delaktighet och platta organisationer. Dock avviker inte det nordiska värdet särskilt mycket från det globala, som således också är högt.

Det nordiska klustret får relativt höga poäng vad gäller att ledarskapet ska vara karismatiskt och värdebaserat. Det innebär specifikt att nordiska ledare förväntas drivas av en realistisk vision, höga prestationsförväntningar och integritet.

Nordiska ledare eftersträvar en något högre grav av oberoende och individualism jämfört med andra länder, men är samtidigt inte särskilt annorlunda än det globala genomsnittet.

\section{Trompenaars}

I korthet kan man säga att de nordiska länderna utmärker sig i Trompenaars studier inom tre av underkategorierna:

- Universalism-Particularism: Norden är i hög grad universalistiskt, vilket innebär att man anser att idéer kan tillämpas var som helst i världen och att det alltid går att skilja mellan rätt och fel. Standarder och värden är viktiga och man kan bara avvika från dessa efter samråd. Det är allmänt accepterat att personer från olika ursprung i samma situationer får samma lön.

- Specific-Diffuse: Norden återfinns generellt inom "specific", vilket betyder att de tror att relationer inte har stor inverkan på arbetet, och även om bra relationer är viktiga ska människor kunna arbeta tillsammans utan att för den sakens skull nödvändigtvis ha en god relation. Man håller även arbete och fritid åtskilda.

- Achievement-Ascription: I en prestationsinriktad kultur, som den nordiska, bestäms en persons värde på grundval av deras prestanda och hur bra de utför sina uppgifter. Omgivningen baserar ditt värde i enlighet med begreppet "du är vad du gör", snarare än att en persons värde kan härledas från bakgrund, familjerelationer eller utbildning.

Därutöver kan Sverige och Finland noteras som påfallande "neutrala" länder. Det innebär att människor anstränger sig för att kontrollera sina känslor och att resonemang påverkar handlingar långt mer än känslor. 


\section{Litteratur}

- Alvesson, Mats. 2009. Organisationskultur och ledning. 2.uppl. Malmö: Liber.

- Andreasson, Ulf. 2017. Tillit - det nordiska guldet. Köpenhamn: Nordiska ministerrådet.

- Berggren, Henrik \& Trägårdh Lars. 2006. Är svensken människa? Gemenskap och oberoende $i$ det moderna Sverige. Stockholm: Norstedts Förlag.

- Berggren, Lars. 2001. Management Strategies among Industrial Leaders in Southern Sweden 1850-1930. I Haldor Byrkjeflot, Sissel Myklebus, Christine Myrvang och Francis Sejersted (red.). The Democratic Challenge to Capitalism: Management and Democracy in the Nordic Countries. Bergen: Fagbokforlaget.

- Byrkjeflot, Haldor. 2003. Nordic Management: From Functional Socialism to Shareholder Value. I Barbara Czarniawska och Guje Sevón. (red.). The Northern Lights: Organization theory in Scandinavia. Köpenhamn: Copenhagen Business School Press.

- Byrkjeflot, Haldor, et al. (red.). 2001. The Democratic Challenge to Capitalism. Management and Democracy in the Nordic Countries. Bergen: Fagbokforlaget.

- Carlzon, Jan. 1985. Riv pyramiderna! en bok om den nya människan, chefen och ledaren. Stockholm: Natur Kultur Akademisk.

- Chokkar, Jagdeep S. et al. (red.). 2007. Culture and leadership, across the world: The GLOBE Book of In-Depth Studies of 25 Societies. London: Lawrence Erlbaum.

- Christiansen, Niels Finn, et al. (red). 2006.

- The Nordic Model of Welfare: A Historical Reappraisal. Köpenhamn: Museum Tusculanum Press, University of Copenhagen.

- Fellman, Susanna. 2008. Finska företagsledare möter svensk modernitet. Modeller för arbetets modernisering och ledning 1930-60. I Anders Houltz, et al. (red.), Arbete pågår - i tankens mönster och kroppens miljöer. Uppsala: Acta Universitatis Upsaliensis.

- Fellman, Susanna et al. 2008. Creating Nordic Capitalism: The Business History of a Competitive Periphery. Red Globe Press.

- Grenness, Tor. 2003. Scandinavian Managers on Scandinavian Management. International Journal of Value-Based Management, 16, (1).
- Guirdham, Maureen. 2005. Communicating Across Cultures at Work. 2. uppl. New York: Palgrave Macmillan.

- Hofstede, Geert. 1980. Culture's Consequences: International Differences in Work Related Valves. Beverly Hills/London: Sage Publications.

- Holmberg, Ingalill och Åkerblom, Staffan. 1998. "Primus inter pares": Leadership and Culture in Sweden. Stockholm: Center for Advanced Studies in Leadership.

- House, Robert J., et al. 2004. Culture, Leadership, and Organizations: The GLOBE Study of 62 Societies. Sage Publications.

- Høie, Tore Audun. 2017. Ethical Management Creativity, Sustainability, Governance. Fringilla Publishing.

- Kalleberg, Ragnvald. 1993. Skandinavisk ledelse og økonomisk kultur $i$ et internasjonal sammenheng. Rapportserien ved sosiologi, 30. Oslo: Institutt for sosiologi og samfunnsgeografi.

- Katzenstein, Peter J. 1985. Small States in World Markets. London: Cornell University Press.

- Larsen, Henrik Holt \& de Neergaard, Ulla. 2007. Nordic Lights: A Research Project on Nordic Leadership and Leadership in the Nordic Countries. Köpenhamn: Kommunernes Landsforening.

- Lekvall, Per (red.). 2014. The Nordic Corporate Governance Model. Stockholm: SNS Förlag.

- Lindell, Martin och Arvonen, Jouko. 1996. The Nordic Management Style in a European Context. International Studies of Management and Organization 26 (3): 73-91.

- Magnusson, Lars. 1987. Arbetet vid en svensk verkstad: Munktells 1900-1920. Lund: Arkiv förlag.

- Morsing, Mette \& Midttun, Atle \& Palmås, Karl. 2007. Corporate Social Responsibility in Scandinavia - A Turn Towards the Business Case? I Steve May, George Cheney \& Juliet Roper (red.). The Debate over Corporate Social Responsibility. 87-104.

- Myklebust, Jan Petter. 2001. The Politics of Organization and Management. I Haldor Byrkjeflot et al. (red.), The Democratic Challenge to Capitalism: Management and Democracy in the Nordic Countries. Bergen: Fagbokforlaget.

- Nielsen, Niels Jul. 1994. Lifelong Care and 
Control - Paternalism in Nineteenth-Century Factory Communities. Ethnologia Scandinavica, 24: 70-90.

- Nielsen, Niels Jul. 2000. Industrial Paternalism in the 19th Century - Old or New? Ethnologia Europaea. 59-75.

- Reve, Torger. 1994. Scandinavian Management - from competitive advantage to competitive disadvantage. Tidsskrift for Samfunnsforskning 35 (4): 568-582.

- Selnes, Fred \& Jaworski, Bernard J. \& Kohli, Ajay K. 1996. Market Orientation in United States and Scandinavian Companies: A Cross Cultural Study. Journal of Scandinavian Management 12 (2): 139-157.

- Sharma, Subhash. 2002. Corporate Rishi Leadership Model: An Indian Model for Corporate Development \& Ethical Leradership. I Udai Pareek, Aahad Osman-Gani, S. Ramnarayan och T.V. Rao, (red.). Human Resource Development in Asia: Trends and Challenges. New Delhi: Oxford and IBH Publishing.

- Sianani, Evis et al. 2008. Corporate Governance in Scandinavia: Comparing networks and formal institutions. European Management Review 5 (1): 27-40.

- Smith, Peter B., et al. 2003. In search of Nordic management styles. Scandinavian Journal of Management 19 (4): 491-507.

- Tollgerdt-Andersson, Ingrid. 1989. Ledarskapsteorier, företagsklimat och bedömningsmetoder. Stockholm: Ekonomiska forskningsinstitutet, EFI.

- Warner-Søderholm, Gillian. 2012. But we're not all Vikings! Intercultural Identity within a Nordic Context. Journal of Intercultural Communication 29: 1404-1634.

- Warner-Søderholm, Gillan \& Cooper, Charles. 2016. Be Careful What You Wish for: Mapping Nordic Cultural Communication Practices \& Values in the Management Game of Communication. International Journal of Business and Management 11(11): 48-58. 

Nordiska ministerrådet

Nordens Hus

Ved Stranden 18

DK-1061 Köpenhamn K

www.norden.org

Nordiska företag och organisationer präglas ofta av engagerade anställda och hög grad av kreativitet. En anledning är en särskild nordisk ledarskapsstil vars kännetecken bland annat är delegering av makt och ansvar till medarbetare samt hög grad av konsensussökande. Den nordiske ledaren betonar också nödvändigheten av samarbete. Han eller hon nedtonar vidare sin auktoritet och fungerar ofta snarast som en slags coach för medarbetarna. Det är också viktigt att ledaren ska inspirera medarbetarna och vara visionär, men samtidigt realistisk.

Denna rapport beskriver hur studier om kultur, ledarskap och värderingar karaktäriserar den nordiska ledarskapsstilen. Rapporten försöker också finna faktorer i de nordiska samhällena som kan bidra till att förklara ledarskapsstilen i Norden. I synnerhet pekas på två faktorer: den nordiska välfärdsstatens utformning samt traditionen av att balansera olika samhällsintressen, inte minst inom arbetslivet. Dessa faktorer kompletteras med att även peka på den nordiska industristrukturens roll. 